New Zealand journal of industrial relations, 1991, 16, 127-142

\title{
The Employment Contracts Act 1991: an employers' charter?
}

\author{
Gordon Anderson*
}

The Employment Contracts Act 1991 radically alters the system of labour law in New Zealand by moving its focus from the collective to the individual level, and the locus from the industry or occupation to the individual employing enterprise. At the same time, the Act significantly shifts the balance of bargaining power further towards employers. The Act also alters the nature of labour law in 2 significant ways: it abandons the system of registered awards enforceable in their own right and instead opts for enforcement through the law of contract, albeit with separate procedures, and it brings all employment contracts within the new regime. This article covers the nature of the changes to the bargaining system and the implications of moving to a labour law regime based entirely on contract.

\section{Introduction}

The Employment Contracts Act 1991 is the most radical reform of New Zealand's labour law and its system of industrial relations since the Industrial Conciliation and Arbitration Act 1894 first introduced the system of compulsory arbitration. The Act not only overturns the last of the premises that underpinned the 1894 legislation but, in addition, largely runs counter to the pluralist premises that have underlaid industrial relations in the majority of developed countries for most of this century, particularly since the end of the Second World War. The Employment Contracts Act also makes a sharp break from the trends in labour law reform that began in 1970 and which reached their peak in the Labour Relations Act 1987. During that period it became apparent that the system of compulsory arbitration which had dominated the law since 1894 was becoming increasingly anachronistic and was, in practice, giving way to a system of direct collective bargaining at an industry, enterprise and occupational level but which took place, for the most part, within the legal framework of the conciliation and arbitration system. The Labour Relations Act completed the process of amending the law to recognize these changes. It also brought other aspects of the law, such as strike law and the limits on the scope of bargaining, into harmony with a collective bargaining system (Anderson, 1990).

The Employment Contracts Act shifts the focus of labour law away from a system based on the collective representation of the interests of workers and the recognition of the inherent inequality of bargaining power in the employment relationship, to one that stresses the primacy of the freedom of choice of individual workers in their relationships with their own employers. The central theme of the new legislation is to locate the centre of labour law and the employment relationship at the level of the individual worker within the enterprise in which the worker is employed, and to move collective organizations to a peripheral role.

This article focuses on 2 aspects of the Employment Contracts Act, the changed nature of bargaining and the role of trade unions, and the change to a contract based

* Commercial Law and Industrial Relations Groups, Victoria University of Wellington. 
system of labour law. It is not, however, intended to discuss the law relating to contracts of employment in depth and the article will instead concentrate on the broader aspects of the changes. First, however, it is useful to briefly consider the capture of the policy and political debate by employer organizations in the period leading up to the Act and the ideological impetus behind the Act.

\section{The political and ideological dimension}

As described above, New Zealand labour law has undergone considerable change over the past 2 decades. For much of that period the reforms were largely agreed between the 2 peak organizations, the Employers Federation and the Federation of Labour. This was particularly true of the major reforms in the Industrial Relations Act 1973, and continued to be the rule until about 1985 . The abolition of compulsory arbitration in 1984 was agreed in a committee where both organizations were represented. The debate leading up to the Labour Relations Act 1987, however, made it clear that the past pattern of consensus-based reform was no longer feasible. The Employers Federation adopted a position that was not only likely to be repugnant to the union movement, but which increasingly viewed unions as anachronistic and marginal to good industrial relations. This position was one facet of the general trend towards the extremist New Right libertarian economic theory that was increasingly adopted by both the Labour Government and by business interests in the period after 1984. These views were most strongly propounded by the Business Roundtable, an organization consisting of the chief executives of many of New Zealand's larger companies. It was the Roundtable that first advocated the type of reforms that were to form the basis of the Employment Contracts Act and which was prominent in lobbying for the reforms. The Roundtable also provided their theoretical justification. This was heavily influenced by such writers as Hayek and Richard Epstein ${ }^{1}$ and stressed freedom of contract and the essentially simplistic view that the general law of contract is sufficient to regulate employment relationships (Brook, 1990). A contrary view of the efficacy of contract law is that "the common law of contract as developed by the Judges has proved demonstrably inadequate to do reasonable justice" (Cooke, 1990, p.2). The Employers Federation were initially slow to adopt the New Right agenda, but after changes to the organization's leadership in 1989 (The Dominion, 13 October 1989), it became increasingly supportive of it. The extent to which the Federation's leadership fully represented the views of all its members, especially smaller employers, is a matter of some debate as there is clear evidence that a significant number of employers were reasonably happy with the existing system (McAndrew and Hursthouse, 1991).

Although the Labour Government had adopted much of the policy of the New Right between 1984 and 1990, it had not applied these policies to the labour market. This was seen as an anomaly by those supporting such policies who regarded the labour market as the remaining major barrier to their programme. The election of a National government in 1990 reopened the possibility for major structural reforms in the labour market and the Government was quick to signal that it saw no place for significant legislative involvement in setting employment standards. One of the first acts of the new Government was to repeal the Employment Equity Act 1990 arguing that legislation was unnecessary to bring about employment equity for women in the labour market. Reform of the labour market had been signaled as a priority in the National Party's election manifesto. The manifesto indicated plans to reform the labour market, but both the manifesto and statements by party spokespersons failed to disclose the full extent of the

1 Epstein visited New Zealand in 1990 as part of the campaign in favour of labour law reform and against employment equity legislation. 
proposed changes. The impetus for reform was no doubt also fuelled by Treasury's desire to see cuts in the level of real wages (The Treasury, 1990).

The Employment Contracts Bill reflected the ability of the Employers Federation and Business Roundtable and their allies to capture the policy making initiative within the National Party and to isolate not only the union movement but to a large extent the Department of Labour from that process. An article by Alastair Morrison (The Dominion, 5 April 1991) details the capture of the policy and drafting process by the New Right not only in the Employers Federation and the Roundtable, but also within the Government, especially by Treasury and the State Services Commission. A memorandum prepared at the time of the draft Bill states that there has been "informal" consultation with the Employers Federation, but that the "NZ Council of Trade Unions and workers ... have not been consulted." 2 Perhaps the Government had come to agree with the Employers Federation that "Society, though, has moved past [the] stage" when unions were needed to assist workers (The Employer, February 1991), and thus they need not be consulted.

This impression was given weight by the process by which the Act was passed, which can usefully be compared with the process that preceded the Labour Relations Act in 1987. The latter Act was preceded first by a government green paper (Department of Labour, 1985) and then a long period of public debate before the introduction of a Bill. The Bill itself was also the subject of considerable debate. In total contrast, the Employment Contracts Bill was introduced with little prior debate and it was made clear that no substantial changes would be made to the policies in the Bill. On being reported back from the select committee the Bill was immediately rushed through Parliament under urgency, a dubious legislative procedure at best. Given the importance of the legislation and the substantial and important changes that were introduced by the select committee, one can only be amazed by the legislative procedures and must seriously question the commitment to participative democracy by the government and other supporters of the Bill. At a practical level the rushed procedure has resulted in an Act that is poorly thought through in legal terms and which contains glaring ambiguities and inconsistencies. Already there has been one amendment to the Act.

\section{The Employment Contracts Act: an overview}

Before discussing particular aspects of the legislation it is worth pausing to consider, in broad terms, the structure of law that the Act has implemented, particularly in the light of the above discussion on the aims of employer organizations. The success of these organizations is most apparent in the provisions relating to freedom of association and the structure of the bargaining process which fundamentally reorientate New Zealand's labour law. Since 1894 labour law has tended to transmit employment rights through the medium of a trade union rather than by conferring directly enforceable benefits on individual workers. A worker's union has been not only the legal vehicle for the representation of the worker in arbitration, and latterly in collective bargaining, but it has also been regarded as the body through which the rights of individual workers are enforced. This latter role was strengthened by the Labour Relations Act 1987 at the same time as the enforcement role of the Department of Labour was substantially reduced. Prior to the Employment Contracts Act, a trade union enjoyed statutory monopoly bargaining rights in respect of all workers within its membership rule, a position that was strengthened in many cases, especially in private sector employment, by a de facto compulsory membership provision. Workers thus had no effective choice as to who 
would represent them in collective bargaining. ${ }^{3}$ The same is true of the rights of workers not to be unjustifiably dismissed. While workers enjoyed this right it was their union that had the right to initiate, or to refuse to initiate, the procedure to enforce that right (Hughes, 1989, para. 4.90 and 4.105).

The Employment Contracts Act has now shifted the focus of labour law to the individual worker. Individual workers are now free to choose whether or not they wish to be represented in negotiations with their employer, and are also allowed a much wider choice of bargaining representative, of which trade unions are only one possibility. The Act has also given individual workers responsibility for enforcing their own employment rights, although again there is the right to do this through a representative. The role that unions retain in labour law is as one agent of choice of individual workers rather than as the centre piece of the industrial relations system. It is the focus of the Employment Contracts Act on the individual worker that is perhaps the most important for the future of labour law. Although the motives for this reorientation and the form in which it has been achieved are clearly designed not to promote individual rights but to de-unionize the workforce, it is difficult to see how (or indeed why) any future reform of labour law will significantly reverse this individual orientation. This remains true even if collective organization and collective bargaining are to be again encouraged and promoted and the legislation strengthened to this end.

Against the greater freedom given to individual workers must be set the attempt of the Act to marginalize trade unions as actors in the industrial relations process. While the Act has allowed workers the freedom to choose their own representatives it has, at the same time, enacted a regime that severely limits the ability of those workers to organize effectively in collective organizations to protect and promote their interests. The Act, in total contrast to all legislation since 1894 , does not recognize or refer to trade unions. It has also largely removed the legal ability of trade unions to gain access to their members in a workplace for organizational purposes and places no requirement on an employer to recognize the union or to bargain with it regardless of the number of employees represented by the union.

The second significant change brought about by the Act is the abandonment of the statutory procedures for the negotiation, registration and enforcement of collective agreements and their replacement by employment contracts that will be governed by and enforced largely on normal contractual principles. This change was one strongly advocated by adherents of the New Right. But as one of the central arguments of the New Right was that a contract of employment was no different from any other contract, and should thus be enforceable through the ordinary courts and on normal contractual principles, the form of this change is disappointing to those advocating it Brook (1991).

The Employment Contracts Act has not only created a specialist tribunal and retained a specialist court, which now have jurisdiction over most aspects of the law of employment, but it continues to subject employment relationships to a specialized legal regime that retains many features of the earlier law. Indeed the Act not only retains those features, but has extended them to all employment contracts including individual contracts of employment previously governed by the ordinary law of contract and which were enforceable in the courts of ordinary jurisdiction. While the future shape of labour law is difficult to predict, one can see in the Employment Contracts Act the potential emergence of an autonomous system of labour law that will be rooted in contract but in time will develop its own individual character.

3 See Anderson, 1986, for the acceptability of these provisions in international labour law. 


\section{The bargaining system}

The most dramatic changes that are brought about by the Act are those relating to collective bargaining. In essence the Act removes state support for collective bargaining and considerably increases the power of employers to either refuse to bargain or to control the course of bargaining that they agree to. This is achieved by reducing the ability of workers to organize collectively and in reducing the powers and rights that collective organizations have to act on behalf of their members. The priority of the Labour Relations Act 1987 was on the collective settlement of terms and conditions of employment. The Employment Contract Act's focus is on the agreement of terms between an employer and employee at the enterprise level, and as such has placed considerable obstacles in the way of collective bargaining and especially multi-employer bargaining.

\section{Trade unions and collective organization}

Since 1894 unions have been central to the system of law that supported New Zealand industrial relations and especially to the arbitration system. The 1894 Act required that the interests of workers be properly represented in conciliation and before the Court of Arbitration. For this reason the legislation granted considerable privileges to unions that registered under the Act including monopoly representation rights for workers within the union's membership rule. The statutory establishment and recognition of unions was, however, bought at a price. Unions were seen as creatures of the state and their functions were to a significant extent subordinated to its purposes. That unions were seen in this light was exemplified by the government's power to deregister unions, and thus to effectively destroy them by administrative fiat (Roth, 1986). This role was, however, usually accepted by unions in return for the privileges granted by the state. This position has however changed over the last 2 decades as unions have adopted what has been termed a mobilizational model of organization (Brosnan et al., 1990, p.98-101). Nevertheless, legally, unions have remained within a statutory structure specifically created for them as part of labour legislation. Indeed, state unions, which had previously operated outside the statutory system, were brought within it in 1988 . By that time, however, the Labour Relations Act had removed most of the legislative restrictions on union objects.

The Employment Contracts Act redefines the role of trade unions in the industrial relations system and significantly downgrades their legal status, a change which it is difficult to see as other than an exercise in marginalizing their role. The view that unions are to be marginalized is supported by the total absence of references to unions in the Act. The Act does refer to an entity called an "employee organization" which is defined as a body "which exists in whole or in part to further the employment interests of the employees belonging to it" (s. 2). Such bodies do not, however, enjoy any particular rights under the Act. Unions are now treated as just one of a number of choices open to individual workers as their representatives and their unique role of collectively improving and protecting the interests of workers is disregarded, if not actively hampered. This means, of course, that the ability of unions to survive and carry out their traditional role will depend on their ability to attract and retain members and to act effectively on their behalf. This will require at least some acceptance of a collective ethos by their membership. This task is one that many unions in New Zealand have rarely had to face and may involve some in the rapid learning of a basic union function. The ability of unions to undertake this task has, however, been severely undermined by the provisions of the Employment Contracts Act. 
Union structures Prior to 1991 unions were registered under and derived their legal status from the provisions of the Labour Relations Act. These provisions included controls on the rules and procedures of unions to ensure their accountability to their members. The new Act has no such provisions and all existing unions are deemed to be incorporated societies and have been re-registered under the provisions of the Incorporated Societies Act 1908. This Act is not necessarily entirely suitable for the effective legal structuring of a union. Unlike the Labour Relations Act, the Incorporated Societies Act has no special provisions regulating the rules of unions and in particular no provisions that will protect union members against undemocratic rules or actions. Presumably such democratic controls are of no concern in the new model of industrial relations in which members will use their new found freedom of choice to leave undemocratic unions. Unfortunately the historical and comparative record is not so sanguine and members are unlikely to have the resources to sue their union or to organize alternatives. Insofar as any body is recognized as representing workers, that body is the employee's representative and that representative may be either an organization or an individual. If the representative is an organization there is no requirement that it possess any of the characteristics of a workers organization such as that it not be "under the domination of employers or employers' organizations" (International Labour Office (ILO) Convention 98).

The right to organize For a union to be able to organize effectively it must have access to potential members and be able to gain recognition from employers as the legitimate representative of its members. Ideally, the law should encourage and promote these needs and limit interference in their exercise, a principle that is central to ILO Convention 98.4 This has been one of the traditional functions of New Zealand labour law, one that was taken to excess in the monopoly rights that were granted to unions. The Employment Contracts Act makes no pretence at promoting collective organization. If anything it hinders it and will make it increasingly difficult for unions to organize, especially as unions lose what advantage they have from an existing membership. Even the minimal freedom of association provisions that remain are objectionable to some New Right adherents who criticize them as restricting competition (Brook, 1991, p.8). Presumably Brook shares Hayek's view that the activities and powers of unions "require limitations by general rules of law far more narrow than those it has been found necessary to impose by law on the actions of private individuals" (Hayek, 1979, p.96).

The Act will only allow unions a right of access to their members once they have been authorized to act as their representative in negotiations for an employment contract, and then only "to discuss matters with that employee regarding those negotiations" (s. 14 (1)). The Act does state that union officials may "with the agreement of the employer" (s. 13) be given access for the purpose of obtaining authorities, but there is nothing to stop an employer refusing such access. The Act thus allows only limited rights of access during negotiations, and that right is written in terms of access to the individual worker and not to the group that the union may represent. It is also notable that a representative has no on-going rights of access to enforce the contract when authorized to do so by the worker. All other rights of access will depend on the union's ability to negotiate such rights during negotiations for an employment contract.

The Act will make union organization extremely difficult, especially when the union faces employer hostility. The Act contains few protections against employers abusing their dominant economic position and their privileged access to workers to manipulate the way in which the workforce is organized. Section 7 prohibits preference in a contract or other arrangement on the basis of membership or non-membership of an employee's organization and section 8 prohibits undue influence in relation to various matters

4 New Zealand has not ratified either Convention 87 (Freedom of Association and the Right to Organise) or 98 (Right to Organise and Collective Bargaining). 
including membership of organizations. The personal grievance provisions also contain some protection for workers in that both "discrimination" (s. 28) and "duress" (s. 30) include anti-union activities. Proof of such activities is however extremely difficult and the penalties minimal. The way thus seems open for employers to have the dominant influence in the majority of enterprises in dictating the form of representation of workers. The choices range from "making the union irrelevant", (as one major employer has stated as being its aim), through house unions to recognizing one or more existing unions.

In some cases, this may only mean a rationalization of the bargaining structure, but in the short period since the Act came into force there is increasing evidence that employers are prepared to use their daily access to workers to counter union organizing activities and to attempt to isolate the union from its members. This includes such tactics as circulating standard form resignation letters and attempting to persuade workers to nominate named union delegates or officials as representatives rather than the union. The latter tactic is presumably intended to limit access as much as possible and to undermine the role that the union can play. It also appears that some employers may be using their daily contact with workers to attempt to sidestep the worker's representative and to attempt to isolate and negotiate directly with the worker concerned. This seems to have occurred even where the worker has appointed the union as their representative and the employer has agreed to bargain with the union.

\section{Bargaining structures}

The greatest contrast that the Employment Contracts Act provides with all labour legislation since 1894 is that the provisions relating to collective bargaining are minimal. Since 1894, legislation has stipulated the procedures for bargaining and the structure of the resulting agreements in great detail. The Employment Contracts Act provides that the type of bargaining and the form of the resulting contracts are a matter for negotiation between an employer and its employees. The Act provides that workers may choose to bargain collectively but neither requires or encourages the employer to agree to this.

\section{Recognition}

One of the greatest weaknesses of the Act from the perspective of both workers and unions is that there are no procedures to require an employer to recognize any union, let alone a majority union, nor to bargain with a union or any other workers' representative. The only obligation is that an employer must recognize the "authority" of a worker's representative (s. 12(2)). What, if anything, such recognition involves is not stated and litigation will be needed to clarify the law. An immediate issue is whether an employer is still free to negotiate directly with a worker where a third party has been authorized to represent that worker. Should an employer refuse to recognize a union for bargaining purposes the union's only alternative would seem to be to resort to strike action. An employer may however be able to avoid this in some cases by taking advantage of the new provisions on the legitimacy of strikes. These are discussed in detail below, but 2 obvious techniques would be to attempt to induce workers to agree to a collective contract by going behind the union or by using the prohibition against strikes over multiemployer contracts. The first technique, in particular, is feasible if workers are unaware that they are entering such a contract or are not aware of the implications of doing so. 


\section{The right to strike}

One of the significant advances in the Labour Relations Act was the establishment of a clear legal right to strike, a major improvement on the confused situation that existed prior to 1987 when strikes in most situations were unlawful, either at common law or by statute (Anderson, 1987). The provisions of the Labour Relations Act have been discussed in detail elsewhere (Hughes, 1989, ch. 11) and need not be covered in detail here. Basically the Labour Relations Act granted immunity from actions founded on the economic torts when a strike was "lawful" as defined by the Act. In general terms a strike was lawful if it related to a dispute of interest and there was either no existing award or agreement, or the existing award or agreement was within 60 days of its expiry date. In the case of such strikes the Act placed no bar on secondary or sympathy action. Strikes were also permitted over redundancy disputes, but the right to strike in such cases was confined to the workers to whom the agreement would apply.

The Employment Contracts Act has not totally negated these gains but it has considerably restricted the scope for lawful strikes and has the potential to make strike action ineffective for the majority of New Zealand workers. The 2 most significant restrictions introduced by the Act are that to be lawful a strike must "relate to the negotiation of a collective contract for the employees concerned" (s. 64(1)(b)) and it may not be concerned with the issue of whether a collective contract will bind more than one employer (s. 63(e)). These restrictions will have the effect of increasingly isolating the unit that is permitted to take lawful strike action by preventing sympathy or secondary action, thus allowing employers to take a much more aggressive approach to strikers. Prior to this Act, employers would have found it difficult to dismiss strikers as most lawful strikes were organized on an industry or occupational basis and an organized secondary response was possible if an employer dismissed strikers. The new law will make it increasingly difficult for unions to provide support for dismissed strikers and employers will find it correspondingly easier to either replace or to rehire strikers on terms dictated by the employer. The bar on strikes over whether a collective contract will bind more than one employer will also benefit employers. Small employers will be able to isolate their workforce and defeat strikes even if the difficulties of organizing a strike in such situations are overcome. Larger employers may now be able to break their business into smaller units, each of which is a separate company and hence a separate employer. This technique was used with some success in the United Kingdom (Wedderburn, 1986, p.555-557 and 597-605). It would then be possible to isolate small groups of workers within an enterprise unless the courts are prepared to pierce the corporate veil and take account of the reality of capitalist corporate structures rather than its legal form.

A further potential limitation on the right to strike in some circumstances will be if an employer is able to persuade its employees to sign a collective contract with an expiry date which extends the contract for an unreasonable period of time. This may be possible where there is no independent representation as many employees may be unaware of the consequences of signing such a document.

The Employment Contracts Act may also have opened a potential door for collective contracts to be challenged where they have been entered into following a strike. Section 57 allows the Court to set aside a contract (in whole or in part) or to award compensation where the Court is satisfied that "the employment contract, or any part of it, was procured by harsh and oppressive behaviour or by undue influence or duress." This provision would seem clearly to encompass a contract, or more likely in practice a variation of contract, obtained as the result of an unlawful strike, such action almost certainly being held to involve both duress and harsh and oppressive behaviour. In the Universe Tankships case (1982) the House of Lords applied the rules relating to duress to allow the recovery of monies paid in the course of an industrial dispute and indicated that industrial action that was not protected by statute could be held to amount to duress (p.75-77). 
More worrying is whether a lawful strike could be held to amount to duress or to be harsh and oppressive. If so, even lawful strike action will face an additional ex post facto obstacle in that a court might see itself as free to decide on the legitimacy of particular types of strike action or whether the object of the strike sought by the workers involved is justified in terms of the economic damage caused to an employer in obtaining it. In resolving this question a court would need to take into account that there is a clear statutory policy that strikes are lawful in certain circumstances. Lawfulness does not, however, mean that there is legal immunity from all the legal consequences of a strike, it merely prevents an action based on the economic torts or founded on a breach of contract. An action based on either duress or harsh and oppressive conduct is not within the immunities provided. It is worth recalling that the English Court of Appeal was tempted to inquire into the reasonableness of strike action (Ewing, 1979) before being reined in by the "graceless intervention" (Ewing, 1986, p.145) of the House of Lords on the eve of the Thatcherite restrictions on unions in that country. In New Zealand there is now the potential for a similar development.

\section{The new employment law}

The Employment Contracts Act has implemented a major restructuring of the law of employment and in particular has legally and procedurally unified the 2 systems of law that co-existed before the Act. The Act has repealed the provisions of the previous law which provided a statutory system for the registration and enforceability of collectively negotiated documents and now requires that such documents be enforced as contracts. Equally importantly, all employment contracts are now brought within the same legal regime, as the Act applies to all contracts of employment including the substantial proportion of contracts that previously were governed solely by the law of contract and which were within the jurisdiction of the ordinary courts. The impact of these changes is potentially far reaching as employment law will now develop in relation to all contracts of employment and the law to be applied will be that set out in the Act as interpreted by a specialist Employment Court. While the Act applies the ordinary law of contract to all contracts of employment there are modifications of that law in the Act and no doubt the decisions reached under the Act will in time come to increasingly reflect the special jurisdiction of the Employment Court.

It is, of course, true that labour law has always contained a strong component of contract law. The employment relationship has always had a contract at its heart, even if the more important terms were fixed by an award or agreement. For the many workers falling outside the collectively organized workforce the law of contract formed the total basis of their employment relationship. In common law systems it has, however, been unusual for collective agreements to be regarded as contracts. The common law position adopted in Ford Motor Co v AUEW (1969) and followed in New Zealand in Re Andrew Patterson Ltd (1981) is that collective agreements are presumed to lack contractual intention and are thus not binding on the parties. These decisions can, however, be criticized and of course the presumption can be rebutted (Hughes, 1989 para. 10.440-445). The terms in such an agreement could also become binding between an employer and employee by becoming incorporated into the individual contract. In both Australia and New Zealand, the system of registered awards and agreements meant that the legal position of collective agreements was in most cases of little importance as legal enforceability derived from the relevant statute rather than the law of contract. Following the Employment Contracts Act the position in New Zealand must now be reassessed. 


\title{
The scope of the Employment Contracts Act
}

\author{
Section 3 of the Act states that:
}

This Act shall apply to all employment contracts and the Tribunal and Court shall, subject to the provisions of this Act, have exclusive jurisdiction to hear and determine any proceedings founded on an employment contract.

An employment contract is defined as a "contract of service" (s. 2), although there is also an extended definition to cover contracts for services between an employer and a homeworker. The definition of an employment contract will raise inevitable jurisdictional problems as to whether a contract is or is not an employment contract and hence whether a dispute comes within the Act or falls within the jurisdiction of the ordinary courts. This may cause inconvenience to the parties but the principles on which the issue is determined are well known, if not always easy to apply (Hughes, 1989, ch. 1). The effect is, however, clear. The Employment Contracts Act sets up a single legal regime which will apply to all employment contracts and in so doing stresses a basic theme of the Act. No longer will there be a special law for collective employment relationships. All employment relationships will now be legally equal with an emphasis on the individual contract.

The Act does, however, distinguish between individual and collective employment contracts, the former being binding " on only one employer and one employee" and the latter binding "one or more employers and 2 or more employees" (s. 2). An employees' representative, may, with the agreement of the parties, become a party to an employment contract. The Act does not however recognize the concept of a collective agreement in the sense of an agreement purely between a union and an employer even if that agreement sets terms and conditions of work. Again the object seems clearly to be to marginalize both unions and the concept of collective bargaining as a primary influence in labour law.

Labour law or employment law? While the Act has brought together all actions founded on an employment contract, it cannot be said to have created a single body of employment law. Harrison (1991, p.42) makes the point that a single dispute may involve the need to bring an action in both the Employment Court and the ordinary courts. Harrison gives as one example the facts of SSC \& B Lintas $v$ Murphy (1986), a case involving a senior employee leaving his employer, taking with him co-employees and documents and files belonging to the employer, and setting up a rival business. The case involved claims in both tort (inducement to breach of contract and conversion) and for breach of contract. It would seem that this case would have to be decided in the High Court as regards the tort action and the Employment Tribunal or Court as regards breach of contract.

A more serious issue, however, is that even a contractual relationship with clear industrial relations implications may fall outside the Act as not being a contract of employment. An employment contract is defined as a "contract of service." This means that the primary parties in terms of the Act must be an employer and an employee. If not, the contract will not be a contract of employment and thus will fall outside the Act. It follows that any contract between a union (or indeed any employee representative) and an employer is not a contract of employment and is thus outside the jurisdiction conferred on the Tribunal and the Court. Such an agreement it would need to be enforced outside the provisions of the Act. If so, the legal status of such agreements could be an issue of contention, especially as, following the Act, such agreements are likely to be informal and ad hoc. It is, however, unlikely that unions would use other than a collective employment contract in any matter of substance, so staying within the familiar jurisdiction and procedures of the Act. The effect is, however, that a useful contractual framework is likely to be denied the participants in collective bargaining. The definition 
of an employment contract, as noted, treats a union as very much a secondary party and conceptually seems to be an unsuitable vehicle for collective negotiations, especially where the issues are related to collective rather than individual issues.

Harrison (1991, p.6-7) makes the additional point that a contract of service is more than just a contract between an employee and an employer. It is also a contract where an employee is engaged to perform work for hire or reward. This means that some contracts will fall outside the Act as they relate to the parties in some other capacity such as mortgagor and mortgagee. It may also mean that a contract on a clear industrial matter, even if the parties include an employer and employees may not be a contract of employment if it does not involve an obligation to work. Harrison uses the example of a "stand alone" redundancy agreement (p.9-10). One hopes that the Act does not herald a return to the days of "industrial matters" and their associated difficulties (Anderson, 1979).

Objections to the changes A major concern relating to the enactment of the new legislation was the decision to bring all employment contracts within the scope of the Act. This decision has major implications for those employees and employers whose contracts were not previously covered by the Labour Relations Act. The relevant provisions were not included in the original Bill and only became apparent when the bill was reported back; a stage when an assessment of the impact of the change was virtually impossible prior to the enactment of the legislation. This is not to say that the change was necessarily bad in principle. Indeed one can argue that it was logical and made good sense, especially in the light of the extension of the personal grievance procedure to all employees. Nevertheless, there are significant reservations that have been raised relating to the effect of the Act on the legal rights of those whose contracts were not previously within the scope of the Labour Relations Act. These reservations have been most forcefully expressed by Dr R Harrison in a letter to the Minister of Labour. 5 Downey (1991) summarizes the objections as follows:

a large section of the population has been deprived of its existing legal rights of access to the ordinary Court system and the normal interpretation of contracts. Existing contracts of service seem to have been effectively amended by statute regardless of the wishes or intentions of the parties .... (p. 145)

One can disagree with some of these points. That all actions founded on an employment contract have been placed within the jurisdiction of a separate Employment Court with a specialized jurisdiction can be seen as a positive legal development for the development of labour law generally. Other points do, however, have considerable strength. The point that the Act has significantly diminished the legal rights of many employees without notice and without their being able to make submissions on the changes is particularly valid. Actions will now be heard by a lay tribunal with wide discretionary powers and rights of appeal to the courts have been significantly reduced. That such disputes may be of considerable legal complexity only adds to this concern. One can only wonder at the policy and thought behind an Act that allows a senior employee bound by a restraint of trade clause only these limited rights, but allows an independent contractor bound by a similar clause access to a more certain body of law and an extended right of appeal. The Act, whether for pragmatic or ideological reasons, has debased the legal standing of the rights of all employees. Employees are subject to a less certain body of law and have more limited access to the higher courts than other citizens.

Downey, rightly, describes the changes as "an act of political arrogance and of legal ignorance regarding the rights of citizens." (p. 145). Unfortunately, he seems to base at least some of his objections on the fact that the Act places senior managers on the same 
legal basis as ordinary workers when it would have been better to encompass the Act as a whole in this description.

\section{The structure of the employment relationship}

The Employment Contracts Act envisages that an employer and employee will be bound by an individual employment contract or by a collective contract although it allows room for a combination of both. The only constraint is that the individual contract may not be "inconsistent" with an applicable collective contract (s. 19(2)). Where there is a collective contract some difficulties may arise. A collective contract must be in writing and must have an expiry date. By its nature it will also be a collective document and be written to cover a group of employees. Consequently, all its provisions are unlikely to apply to all employees or be exhaustive of the relationship between an individual employee and their employer. For this reason it would seem that an individual employee will need to be bound by a separate individual contract, which may be a minimal contract that merely specifies where the individual is fitted into the collective contract. The individual contract is also likely to be the vehicle which initiates the employment relationship that gives continuity of employment and to which the common law implied duties are attached. The collective contract will, however, spell out the principal terms of the employment relationship.

Continuity of employment, and especially the terms of the continuity, become particularly acute on the expiry of the collective contract. Section 19(4) provides that on the expiry of the collective contract "each employee who continues in the employ of the employer shall ... be bound by an individual contract based on the expired collective employment contract." This provision does not provide explicitly for continuity of employment, the words "who continues in the employ of" being somewhat ambiguous, although continuity would seem to be envisaged. The more practical problem would seem to what is meant by "based on" the expired contract. The minimal interpretation would seem to be that all terms of the collective contract that applied directly to the individual at the time of the expiry would be carried forward. More problematic is those terms that are for the benefit of the individual but which are collective in nature such as union access rights. Until these problems are resolved by litigation the most sensible approach would seem to be to express such rights as individual rights wherever possible. Thus an individual employee would have the right to be visited by their union representative rather than, or as well as, the union having access rights to members.

\section{The law of contract and the Employment Contracts Act}

The aim of regulating employment relationship by the normal law of contract is at the heart of the reforms in the Act. In general terms that aim has been carried through into the legislation. Some problems do, however, remain to be addressed or clarified. The most obvious are those touching on the relationship between an individual contract and a collective contract, a situation not helped by the assumption made in drafting the Act that provisions in the Labour Relations Act applying to awards can appropriately be applied to collective contracts. In other areas the law of contract has been modified and discretionary powers vested in the Tribunal and Cnurt may affect the strict terms of a contract. It is not intended to discuss these issues in any detail and only the main issues will be noted. There are, however, significant technical problems raised by the Act (Harrison, 1991).

The jurisdiction of the Tribunal and Court In general the ordinary law of contract as it has been developed by the courts in employment cases will govern 
employment relationships. The Court's jurisdiction includes the ability "to hear any action founded on an employment contract" (s. 104(1)(g)) and to make "any order that the High Court or a District Court may make under any enactment or rule of law relating to contracts" (s. 104(1)(h)). There are, however, 2 important restrictions on these powers. The first is that contained in section 104(2) which provides that the Court shall make an order cancelling or varying a contract under subsection (1)(h) "only if satisfied beyond a reasonable doubt that such an order should be made and that any other remedy would be inappropriate or inadequate." The reason the Court should be directed to apply a significantly higher requirement in cases involving employment contracts than that which the ordinary courts apply in other civil cases is difficult to understand and the rationale behind this provision escapes the author. This provision will affect the granting of the remedies provided in all the major acts affecting the general law of contract.

The second provision is that both the Court and the Tribunal have jurisdiction to make decisions in "equity and good conscience" (s. 79(2) and 104(3)). The exercise of this power may not, however, be "inconsistent with this or any other Act or with any applicable employment contract." This provision has, under the previous legislation, given the Court a useful discretionary power (Hughes, 1989, para.9.150-155). The logic of the form of the provision, which seems to have been carried over from the Labour Relations Act with little thought, is now somewhat suspect. As the difference between a collective contract and an individual contract may be so small as to be meaningless, the reason for excluding collective contracts but not individual contracts from the equity and good conscience provisions is not apparent. The fact that the Labour Relations Act contained a provision to exclude awards and agreements must be seen in the context that such documents were negotiated by an independent union and covered significant groups of workers. This is no longer the case. The difference between a collective contract and an individual contract under the new law may merely be that an employer has convinced a group of workers to sign a single standard form contract rather than have each individually sign their own copy of exactly the same contract. The form of the limitation fails to adequately reflect the change from awards to contracts and thought needs to be given to its appropriateness and to its form under the new Act.

Harsh and oppressive contracts A major substantive change to the law of contract that has been made by the Employment Contracts Act in section 57. The 2 relevant parts of this section provide:

57. Harsh and oppressive contracts- (1) Where any party to an employment contract alleges-

(a) That the employment contract, or any part of it, was procured by harsh and oppressive behaviour or by undue influence or duress; or

(b) That the employment contract, or any part of it, was harsh or oppressive when it was entered into,-

that party may apply to the Court for an order under this section.

(7) Except as provided in this section, the Court shall have no jurisdiction to set aside or modify, or grant relief in respect of, any employment contract under the law relating to unfair or unconscionable bargains.

It would seem that these provisions may be of more use to employers attempting to challenge contracts concluded after a strike than to employees attempting to challenge either a collective contract, a point discussed above. An employee attempting to show that either behaviour or a term of the contract were both harsh and oppressive would seem to face an extremely difficult hurdle. It is worth comparing this provision with the analogous provision in the Credit Contracts Act 1981. This Act allows the courts to reopen a credit contract that is "oppressive" and oppressive is defined as meaning "oppressive, harsh, unjustly burdensome, unconscionable or in contravention of 
reasonable standards of commercial practice" (s. 9). A similar provision in the Employment Contracts Act could allow some room to attack the more exploitative contracts that are likely to flow from the changes to the law. Workers do, however, have some protection from oppressive conduct by employers through the personal grievance procedure once employment has commenced.

\section{Conclusion}

The title of this article asked the question: is the Employment Contracts Act an employers' charter? The discussion above makes it clear that the Employment Contracts Act has seriously eroded the collective rights of workers and consequently their ability to protect their individual interests in employment relationships. The Act ignores industrial relations experience in the great majority of countries that are comparable to New Zealand and instead relies on a dubious economic ideology based on unrealistic a priori assumptions, and which ignores features of real-world labour markets. It is already clear from news reports that employers are taking advantage of the lack of collective protection and the economic climate to force major reductions in wages and conditions and to attempt to de-unionize their workplaces. The predictable effect of the Act will be the development of a 3 tier labour market. Those workers who traditionally fell outside the scope of the Labour Relations Act will probably notice little change. If anything their position has been improved by the significant increase that they will gain in the security of their employment through access to the personal grievance procedure. Workers previously within the coverage of the Labour Relations Act will almost certainly divide into those permanent workers employed by larger employers, who are likely to retain their ability to negotiate collectively and to collectively protect their conditions, and those who work for smaller employers and who are in traditionally vulnerable groups. The latter group will become increasingly isolated and subject to the dictates of their employers. The most positive feature of the Labour Relations Act was that through the national award system it provided a basic level of protection to the most marginal and vulnerable groups of workers in the labour force. Such workers must now rely on the minimal protections provided by such statutes as the Minimum Wages Act 1983 and the Holidays Act 1981. To give a positive answer to the question posed above one need only consider the effect of the Act.

What then of the future? It is clear that as a piece of legislation the Employment Contracts Act makes no attempt to balance the interests of workers and employers. It is a partisan piece of legislation which needs considerable change to become acceptable in a pluralist society. The Act does however form a base from which reforms can be mounted. The Labour Relations Act contained many features which needed reform and which had, perhaps, outlived their historical context. Union monopoly bargaining rights and the consequent lack of choice for workers were one such feature. Another was the complex institutional arrangements surrounding the negotiation and registration of awards and agreements. That there was room for reform is clear. The issue was not the need but the form, and it is the form that must now be reconsidered. The Employment Contracts Act has 2 features that offer a base for future reform. The decision to bring all contracts of employment within the one system of law is a major advance. Equally important was the decision to retain the system of specialist labour tribunals that has served the country well over almost a century. The Employment Court has, in the past, shown the potential to develop a balanced approach to labour law and employment issues, an expertise that in general has been recognized by the Court of Appeal. If this trend continues, an autonomous labour law with roots in both the law of contract and in the realities of industrial life, may develop enabling the law to escape from the worst aspects of the common law approach to the employment relationship. The development of a genuine and autonomous law of employment may then become possible (Wedderburn, 
1987). For this to occur, however, the Employment Contracts Act will need considerable reform.

The first and most straightforward reform is to re-examine the law of contract and ensure that it is adapted to the needs of labour law. This is not a novel exercise and indeed the Employment Contracts Act in requiring all contracts to contain a disputes and a personal grievance procedure has already commenced this process. Statutory reform of contract law both generally and in specialist areas of the law is nothing new, and one need only consider the Contractual Remedies Act 1979 or the Credit Contracts Act 1981. A more difficult issue is how to reform the provisions relating to the right to organize and for collective bargaining. Again this is not an insurmountable task. Clear international standards exist and there are many precedents. To adapt New Zealand law to these standards requires not so much expertise, although that is invaluable, but a government that recognizes that a pluralist democratic society must accept that workers have these rights. Reforms to promote collective bargaining will not, however, necessarily be sufficient to protect the bottom tier in the labour market nor even the most appropriate method. Collective bargaining has been criticized for not adequately recognising the needs of marginal workers (Conaghan, 1986). Perhaps what may be needed is the redevelopment of the concept of a social state and within it a closer integration between such a social law and employment law.

\section{References}

Anderson, G. (1979) Jurisdiction under the Industrial Relations Act 1973: some problems and issues. Wellington, Industrial Relations Centre, Victoria University of Wellington (Occasional Paper No. 24).

Anderson, G. (1987) The reception of the economic torts into New Zealand labour law: a preliminary discussion. New Zealand journal of industrial relations 12(2):89-100.

Anderson, G. (1990) Developments in the legal regulation of collective bargaining in New Zealand. Australian journal of labour law 3(3):227-246.

Brook, P. (1990) Freedom at work: the case for reforming labour law in New Zealand. Auckland, Oxford University Press.

Brook, P. (1991) The Employment Contracts Act: two steps forward, one step back. Public sector 14(2):8-9.

Brosnan, P., Smith, D. and Walsh, P. (1990) The dynamics of New Zealand industrial relations. Auckland, John Wiley.

Conaghan, J. (1986) The invisibility of women in labour law: gender-neutrality in model-building. International journal of the sociology of law 14:377-392.

Cooke, R. (1990) The dynamics of the common law. In Conference papers, 9th Commonwealth law conference, Auckland, Commerce Clearing House.

Department of Labour (1985) Industrial relations: a framework for review. Wellington, Government Printer.

Downey, P. (1991) Work and contract. New Zealand law journal (May):145-146.

Ewing, K. (1979) The golden formula: some recent developments. The industrial law journal 8(3):133-146.

Ewing, K. (1986) The right to strike. The industrial law journal 15(3): 143-160.

Harrison, R (1991) The Employment Contracts Act 1991: some key legal issues. Auckland, Auckland District Law Society. 
Hayek, F. (1979) Law, legislation and liberty. London, Routledge Kegan and Paul (Volume 3).

Hughes, J. (1989) Labour law in New Zealand. Sydney, Law Book Co.

McAndrew, I. and Hursthouse, P. (1991) Reforming labour relations: what southern employers say. New Zealand journal of industrial relations 16(1):1-11.

Roth, H. (1986) Legalised theft by deregistration. New Zealand journal of industrial relations 11(1):21-26.

The Treasury (1990) Briefing to the incoming Government. Wellington, The Treasury.

Wedderburn, Lord (1986) The worker and the law. Harmondsworth, Penguin (3rd edition).

Wedderburn, Lord (1987) Labour law: from here to autonomy? Industrial law journal 16(1): 1-29.

\section{List of cases}

Ford Motor Co.v Amalgamated Union of Engineering Workers [1969] 2 Queen's Bench Reports 303.

Re Andrew Patterson Ltd [1981] 2 New Zealand Law Reports 289.

State Services Commission \& B Lintas v Murphy [1986] 2 New Zealand Law Reports 436.

Universe Tankships Inc of Monrovia v International Transport Workers Federation [1982] 2 All England Law Reports 67. 